\title{
旧樺太守備隊司令官宿舎（1908） THE PRESENT STATE OF THE の現況と設計者について FORMER OFFICIAL RESIDENCE FOR THE COMMANDER OF KARAFUTO- GUARDS (1908) AND ITS DESIGNER
}

\section{角 幸博 一 * $* 1$ 井澗 裕 一 $* 2$ 石本正明 - $* 3$ \\ キーワード \\ サハリン, 櫵太, 樺太守備隊, 官舎, 田村鎮}

Keywords :

Sakhalin, Karafuto, Karafuto guards, Official residence, Yasushi Tamura

\section{Yukihiro KADO - $* 1 \quad$ Hiroshi ITANI — $* 2$ Masaaki ISHIMOTO $-* 3$}

We describe the history and the present state of the Official Residence for the Commander of Karafuto-Guards, which was completed in 1908. We also deal with its suspected designer, Army Architect Yasushi Tamura (1878-1942), who is known as the designer of the Divisional Headquarters Office of the Imperial Guards. The official residence has high value in the modern architectural history not only because it is one of the oldest buildings of the Japanese colonial period in Sakhalin, but also because it was a dwelling house built for the people of highest class in Sakhalin.
1. はじめに

戦前期日本の海外植民地における建築活動に関する研究は、1980 年代頃から実施されている1)。一方、南サハリン(旧樺太)における日本 統治期の建築活動については、筆者らの一連の研究 ${ }^{21}$ はあるものの、 まだ不十分といわざるを得ない。現存する日本期の主要建築について は、井澗裕ほか「南サハリンにおける日本統治期 (1905 1945) 建

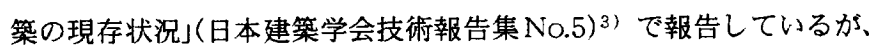
㮖太庁豊原医院(現ロシア陸軍病院、1931)、樺太庁中央試験所本館(現 ロシア科学アカデミー極東支部サハリン科学センター、1934)、槿太 庁博物館(現サハリン州郷土博物館、1937)、樺太庁会議室(現ロシア軍 関連施設、1934)、北海道拓殖銀行豊原支店(現サハリン州立美術館、 1931)、北海道拓殖銀行大泊支店(現コルサコフ市所有建物、1929)、 㮖太守備隊司令官宿舎(現ロシア陸軍法務局サハリン州軍管区裁判所、 1908)などが挙げられる。

このうち、樺太守備隊司令官宿舎について、1999 年 5 月 31 日、6 月 1 日および 2000 年 9 月 22 日に、主に平面・立面図作成のための 実測調查を実施することが出来た。現役の軍区裁判所という建物の性 格上、調查時間の確保が難しく十分な調查とは言い難いが、州行政 府、軍管区裁判所および州郷土博物館の協力により調査が実現できた ことは、近年の日口友好関倸の進展の結果である。本稿は、実測調查 結果をもとに、旧樺太守備隊司令官宿舎建物の沿革と現況、設計者に 関する考察をふまえ、本建物の史的価値について報告し、本建物の今 後の取り扱いについて、日本とロシアやサハリン州の友好協力によつ て、一刻も早い保存修復の一助となることを期待するものである。

\section{2. 旧樺太守備隊司令官宿舎の沿革}

司令官宿舎は、1908 年 11 月頃に旧豊原東 3 条南 1 丁目、樺太守 備隊司令部の南向かいの追分通（のちの真岡通、現サハリンスカヤ 通）を挟んだ位置に建設された4)。設計は、後述の樺太守備隊司令部 建築係、陸軍技師田村鎮と推定され、建設は北海道の建設業者伊藤黾 太郎(現伊藤組)が43,451 円62 銭で請忛負つた ${ }^{5}$ 。同建物については、 竣工以来少なくとも 4 度の転用が確認されている。1913年 4 月 24 日 付守備隊撤退後、1920年9月 1 日に樺太庁博物館に転用された ${ }^{6)}$ が， 1934 年に豊原憲兵分隊設置とともにその庁舎として利用された。第 二次大戦末期には樺太守備部隊(陸軍第 88 師団)司令部として利用さ れ、現在はサハリン州軍管区裁判所として使用されている。

\section{3. 樺太守備隊と建築活動}

守備隊司令官宿舎の概要にふれる前に、樺太守備隊について説明し ておこう。端的に言えば、樺太守備と陸軍諸施設の建造と保護を目的 とした第7師団(北海道旭川)隷下の組織である。1904(明治 37)年勃発 の日露戦争で、日本軍は 1905 年7月 28 日、全島占領を宣言した。 9 月 3 日に日露休戦条的が成立し、9月 7 日樺太守備隊司令部が設置さ れた。同年 8 月 28 日には占領地域に民政署が設置されている。民政 署は、占領地域の秩序維持を目的におかれる臨時行政機関で、重要な 決定洔守備隊司令官の裁可を必要とし、活動予算も陸軍省からの臨時 軍事費から捻出された。また兼任や嘱託が多く、人事面でも定員など の制約が厳しい組織であったと推察される。

樺太民政署は 1907 年 4 月 1 日廃止され、槿太庁が設置される。樺

\footnotetext{
*1 北海道大学大学院 助教授・博士 (工学)

(二060-8628 札幌市北区北13西8)

*2 小㴊フェローシップ 研究員・博士 (工学)

*3 北海道大学大学院 助手・博士 (工学)
}

*1 Assoc. Prof., Graduate School of Eng. Hokkaido Univ., Dr. Eng.

*2 Researcher., Obuchi Fellowship., Dr. Eng.

*3 Research Assoc., Graduate School of Eng. Hokkaido Univ., Dr. Eng. 
太民政署・樺太庁共に陸軍の隷下組織であり、統治期初期においては 樺太守備隊の建設工事とほぼ並行して、民政署・樺太庁による官吾建 設工事が行われていた。

樺太守備隊司令部の構成はほぼ毎年のように変化するが、1907年 で、司令官 1 、参謀 1 、副官 2 、主計正 1 、主計 2 、軍医正 1 、技師 1、属 1、技手 5(名)であった。主計(経理担当保官)や軍医も、直属の 上位組織は、第7師団の経理部や軍医部で、その動静はそれぞれの上 位組織の長に「区所を受ける」 ${ }^{7)}$ 必要があった。1907年 4 月現在の 構成員一臨 ${ }^{8)}$ の中で、建築技術者之考えられるのは、田村鎮(技師)、

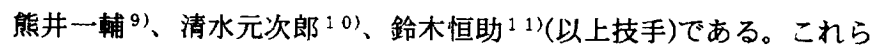
の技術者は、1907(明治 40)年から1909年にかけて、つまり豊原で守 備隊施設工事が実施されていた時期にのみ配属されており、樺太守備 隊守備隊営地の建設工事への技術者投入であることは明らかである。 1909 年以降は技術者の赴任は無く、守備隊の営繥組織は臨時的性格 であつたと考えられる。この期間に建設された主要建物として、司令 官宿舎の他、司令部庁舎(1907 年 11 月 30 日竣工、30,214 円 25 銭)、 衛戍病院(1908年10月 31 日竣工、122,474月)、宿舎・共同浴室(1908 年 8 月 30 日竣工、 3,306 円 20 銭)などがあげられる。

\section{4. 旧樺太守備隊司令官宿舎の現況}

\section{1 外観 (写真 1 )}

かつての真岡通(現サハリンスカヤ通)に正面を向けているが、丁度 この建物をコの字型に囲んで集合住宅(クバルティーラ)が建つため、 通りからはみえない。旧来の正面は北面であったが、現在正面玄関は 閉鎖されている。北側正面の左右非相称の大小 $2 \supset$ 三角ペディメン トが特徵的である。1 階棟瓦造、2 階木造で、主棟は寄棟屋根。外観 は上下階で水平分節し、創建時の写真(写真 2)によれば、1 階と 2 階 とで色を筀り分けたツートンカラーの建筑であった。南面には木造平 屋切妻平入の下屋を設けていた。外壁は四周ともモルタルで塗り固め られ、現在は薄楼色の彩色を施こしている。

外観デザインはネオ・ゴシックを意識し、玄関晋りに影著にゴシッ ク要素を展開している。槂形は、旧状をよく残しているが、2 階外壁 のリブの呅失、2 階北面中央バルコニーの室内化、2 階北面バルコ ニ一欗間の三葉アーチ飾りの哇失、1 階北面西側パルコニーの改変、 空建具の変更など細部変更と、主屋と付属屋接合部の玄関増築などが 指摘される。特に、北面西側の 2 階バルコニーのたわみと 1 階旧バル コニー部の胴コーニスの漆喰装飾や外壁の剥離は目視できるほど大き い。主棟南側に付属する現法廷は、切妻平家で、創建当初の板張り外 壁を現在はモルタル塗に改修している。屋根は屋根材を含め改変はほ とんどないが，真板や妻面各部に傷みが目立つ。

用途変更は前述の通り多いが、豊原憲兵分隊時代の古写真(写真 3)

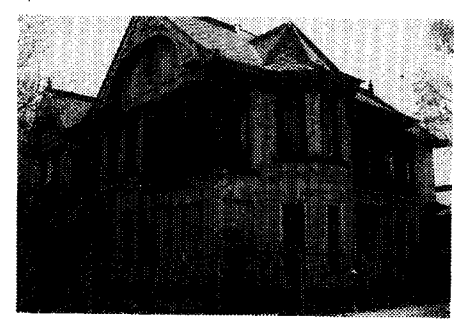

写真 1 旧苹太守備胼司令官宿全現況

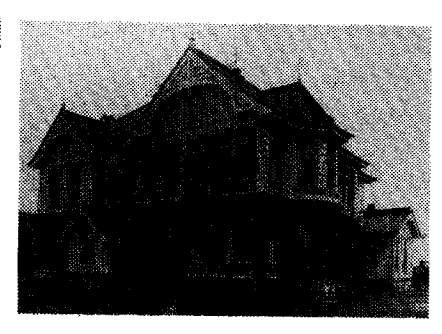

写真2 創建時の樺太守備隊司命官宿舎 （伊藤組蔵）

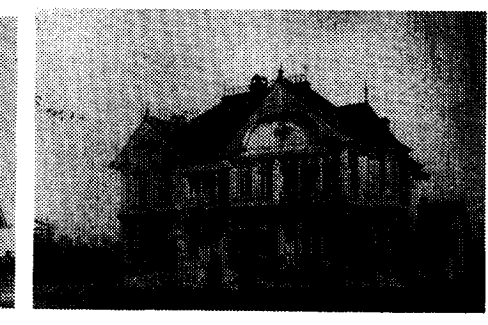

写真3 壹原害兵分隊時代の旧司令官宿舎 (『樺太庁施政 30 年史』より)
を見る限り外観上大きな改修点はなく、主な改修はソ連時代になされ たと考えられる。図 1 は現状、図 2 は痕跡調查と古写真から復原した 北側正面立面図である。

\section{2 内部}

建物は、逆 L字型主棟の南側に平家が付属し、主棟は最長部で南 北 $17,080 \mathrm{~mm}$ (56.4 尺)、東西 $20,200 \mathrm{~mm}$ (66 尺)、従棟は析行(東西) $13,800 \mathrm{~mm}(45.5$ 尺)、梁間(南北)6,370 mm(21 尺)である。1 階主屋 76.1 坪、平家 35.4 坪、2 階 78.5 坪、延べ床面積 190 坪である。

1 階(図 3)は、北面中央の旧玄関ホールに間仕切り壁が補設され、 所長室(現在未使用)、副所長室、判事室、守衛室の他は未整理の文書 庫としている。旧玄関ホール、判事室・所長室、副所長室には、暖炉 が遭存する。南側付属室は、法廷、独房として使用している。旧玄関 ホール西側の階段は、反時計回りのゆるやかな知り階段で、親柱や手 摺り子などに旧状をよく留めている。階高は $4,275 \mathrm{~mm}$ と実測され た。

2 階(図 4)は、軍事務長室・秘書室などとして利用し、1 階と同位 置に暖炉を配置する。西側のベイウインドーをもつ比較的大きな部屋 は、応接間や居間などに使用されたと考えられるが、暖炉などの暖房 装置はみられず、現在は未使用である。小屋重では棟札は発見できな かったが、小屋組はキングポストトラス、暖炉の煉瓦造煙突は、使用 煉瓦からソ連時代の改修であることを確認した。

\section{5. 設計者}

本建物の設計者を直接示す資料はないが、槿太守備隊司令部付陸軍 技師として建設活動を推進した田村鎮の可能性を指摘しておきたい。 資料として、防衛庁防衛研究所戦史資料室所蔵 P明治三十七八年戦役 陸莗政史 第六巻」(陸軍省編纂)、北海道大学附属図書館所蔵 P明治職 官表」(内閣書記官室記録課、1907)、『帝国大学出身名鑑」(佼友協会、 1932)、『建築雑誌」昭和 17 年 4 月号「田村鎮君を悼む」(日本建築学 会、1942.4、記事は中村与資平筆)、東京帝国大学工学部建築学科付 属図書館所蔵の技術者カード「田村鎮」を用いた。

田村は1878(明治 11)年 10 月 24 日、東京府芝区で生まれた。学習 院を経て東京帝国大学建築学科に入学、1905(明治 38)年卒業し、ま ず雇員待遇で陸軍省に奉職した。翌年、陸軍技師に任官、樺太守備隊 司令部付となり、ほぼ同時に樺太民政署御用掛兼勤の辞令を受けてい る。この時点まで㮖太民政署には建築技術者はいなかつたようなの で、彼の赴任まで民政署は本格的な建築活動をしていなかったと考え られる。また、この時期慒原の区画測設がほぼ終了し、守備隊営地 建設計画が始動する時期であった。防衛庁戦史資料室所葴『明治三十 七八年戦役陸軍政史 第六巻」によると、1905年 8 月 11 日発令の満

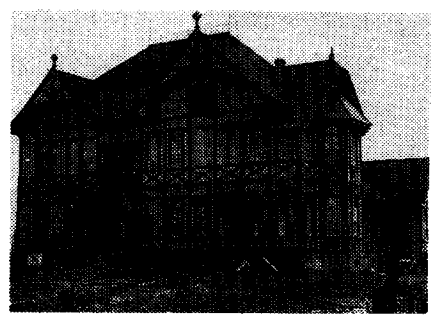

写真4 樺太厅長官官舍 (伊丽組葳) 
発第 6932 号として以下の既述がみられる。

「分月十一日 第十三師団における兵舎倉庫等建築工事に従事せしむる為、陸軍 省誳員工学士田村鎮を㮖太に派遭するに決し左の事項を訓令し、其旨次官より 参謀次長に申牒し、其向へ通達方要求す

1 ・建筑工事の業務に就ては第 13 師団兵帖監部附建築主任官の指示を受くべし 2 ・将来建築すへき永久建築物に就き、左記の事項を調查研究の上報告すへし 个該地の風土に適する建築物の概要

口 兵舎宿舎及庁舎の採温方法

八 冬季における点奵の方法

二 給水の方法

木 樺太島に於ける建築用材の品種価格及利用の方法

へ 将来建築用材としてし得き品種及其方法」

田村には、南サハリンにおける建築の構造や構法を研究する義務が 課されていたのである。残念ながら、この訓令に対する彼の報告書は 見つかっていないが、田村が技師職であったことを考え合わせれば、 樺太守備隊の諸建筑は彼の研究結果に基づくものと考えるべきであろ う。しかし、田村鎮はまだ帝大を卒業したばかりである。実務経験の 乏しい彼を補佐した技術者の存在は充分考えられるが、現段階では不

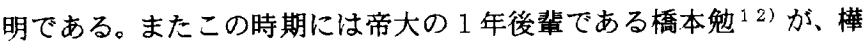
太民政署嘱託技師として任ぜられている。この点も田村の招聘と考え られるが確証はない。

1906年 3 月 31 日、民政署は廃止となり翌日樺太庁が開庁する。田 村も 4 月 1 日付けで樺太庁技師兼任陸軍技師を任じられ、5月 1 日に 再び槿太守備隊付の辞令を受けている。この時点から彼を中心とする 守備隊司令部建築係あるいは槿太庁建築課の一員は、諸官庁の設計を 開始したものと考えられる。いずれの組織も少人数の組織であり、し かも要求されている建築物恃多数にわたるため、両方の長を努めた田 村は多忙を極めたと推察できる。彼の南サハリンでの活動は、1908 (明治 41)年 6 月 30 日付けで、陸軍技師専任、陸軍臨時建築部本部付 の辞令を受けるまで続いた。

主要建築物の着工日を伊藤組所蔵の工事請負契約書から確認する と.

樺太守裳隊司令部庁舎 衛成病院宿舎 ·付属屋 衛成病院・付属屋 守備隊司令官宿舎

1908 (明治 41)年 2 月 8 日

同上

同上

守備隊司令部暖炬格納庫 $1908($ 明治 41)年 5 月 23 日

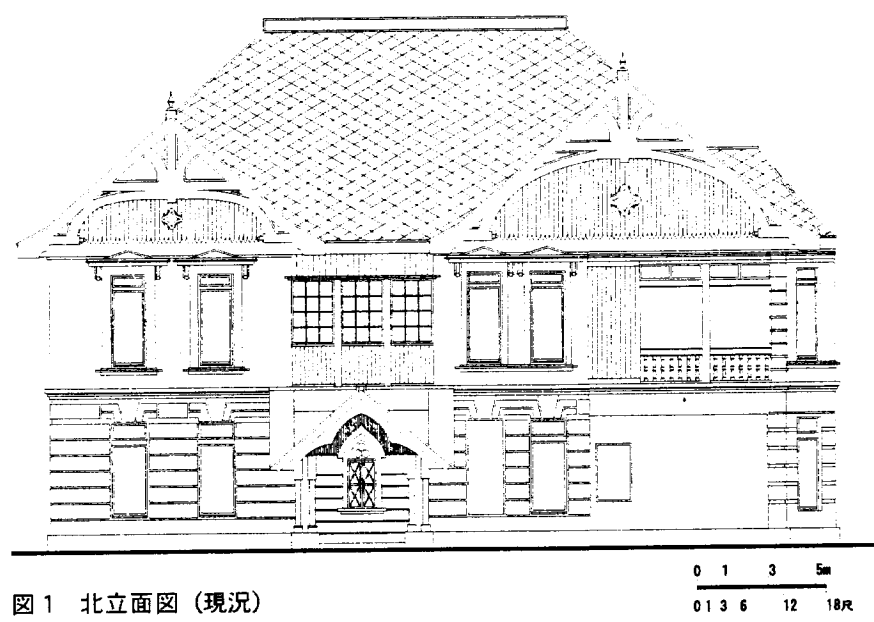

というように、6月 30 日段階ですでに設計を終えて工事に入ってい ることがわかる。そのため、田村鎮の転任時点で主要建築の大方の設 計作業が終了していたと考えるのが妥当で、設計作業後に転任したと 考えられる。樺太庁技師としての具体的活動を示す資料はないが、唯 一の建築技師であった彼の役割は大きかったと見るべきであろう。彼 自身も若かったが、彼の周りの技手たちも同様に学校を卒業したての 若者ばかりだったからである。

1908(明治 41)年 6 月 30 日付けで東京へ転任した田村は、陸軍踟時 建築本部付けとなる。ここで彼は近衛師団司令部庁舎(現国立近代美術 館工芸館、1910 年、重要文化財)の設計に擭わつた。その後は、軍用 気球の研究委員会に属したり、欧米への出張などがあるが、具体的な 建築活動については不明である。陸軍技師退官は 1920 年、その後は 東京啮谷で建築設計事務所を経営した。この時期の活動も明らかでは ないが住宅設計を主とした ${ }^{133}$ らしい。1929 年頃から 1936 年頃ま では、「建築学会会員名簿」で「田村鎮建築設計事務所」の項を確認 できる。『建築雑誌」(昭和 17 年 4 月号)「田村鎮君を悼む」で、中村与 資平は田村の人柄について、趣味は多岐に渡り、俳句、囲碁・将棋、 ビリヤード、謡曲などをたしなみ、その生活は「䁈沢からは完全に手 を切って」「徹底的に無頓着な」一生を趣味に貫いた」「㢣々乎とし た高い風格」「誰に対しても丁寧根切を極め、いはぐ地味な性格の人 と評されるもの」と伝えている。

\section{6 . 旧樺太守備隊司令官宿舎の歴史的評価}

守備隊司令官は、樺太庁長官よりも上位であった。樺太守備隊司令 官宿舎は、樺太で最高位にあった者が居住する住宅建築である。重虽 かつ華やかな印象を与える外観は、当時の豊原市街でも耳目を集める 意匠であったと考えられる。この司令官宿舎は、やはり伊藤組によつ て建てられた槿太庁長官官舎（1908 年ころ、写真 4）とよく似たデ ザインをしている。基本的平面は同じで、別な意匠を施したともいえ るかもしれないが、長官官舎の軽快さに対して司令官宿舎は同じゴ シック様式でももっと豪奢な印象すら与え、守備隊司令官と槿太庁長 官の職差が建築デザインに反映したものとも考えられる。その類似性 は、槿太守備隊、樺太庁が互いに協力体制をとつたり、影響を及ぼ しあっていたこことの証左である。両者の建築組織が、田村鎮技師によ り統括されていたことと、深い関係のあることも推察される。

さらに 1 階を煉瓦造とし暖炉を設置するなど、寒冷地に適応した建

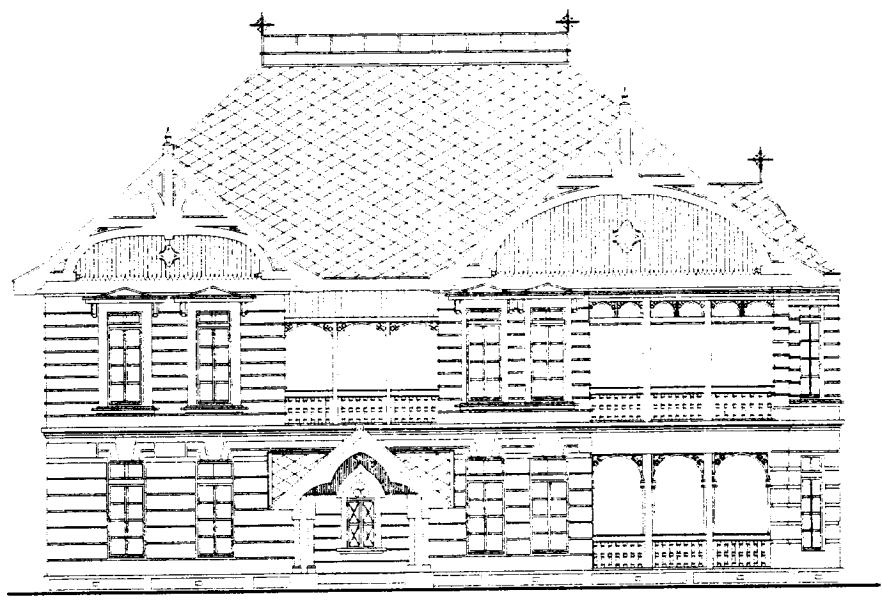

因 2 北立面図（復原） 


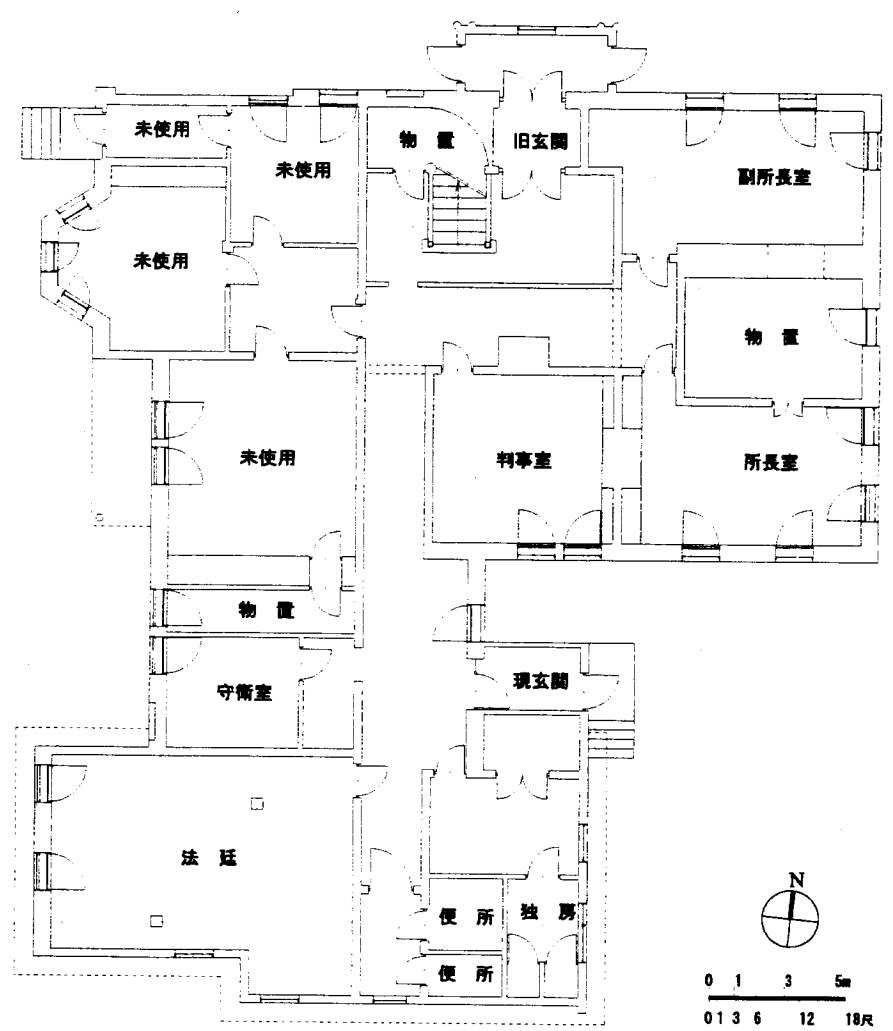

図3 1 階平面図（現況）

築を模索する一方で、防寒的に不利なバルコニーを多用し、南面下屋 の雪処理を考虑しない屋根形状などの矛盾も指摘される建築である。 また、設計に田村鎮の関与を指摘できる建築であり、田村の代表作近 衛師団司令部庁舎以前の活動を示すものとして、またこれまでに確認 されたサハリンにおける統治期建造物の中で現存最古である点かつ 当時の最高職位用の住宅建築としても注目され、その史的価値は極め て高いといえる。

平面や詳細な立面に関する充分な復原考察は課題として残されてお り、かつ軍事施設であるため、積極的な保存活用提言は難しいが、竣 工後 90 年以上経過し、傷みも目視されるようになっており、日ロ両 国による一刻も早い修理修復の必要性を強調しておきたい。

\section{謝辞}

本研究は、(財) 住宅総合研究財団平成 10 年度研究助成および平成 12 年度文部省科学研究費補助金 (基盤研究 (B) (2) 課題番号 12572027）の助成を得た。また、実測図作成にあたり北海道大学大 学院学生角哲君の協力を得た。ここに記して謝意を表する。

\section{注記}

1) 越沢明『植民地満州の都市計画」(アジア経済研究所、1978年)、同『满州 国の首都計画」(日本経済新聞社、1988 年)、同 P哈爾浜の都市計面」(総 和社、1989年)、西澤泰彦 $\mathbf{2} 20$ 世紀前半の中国東北地方における日本人の 建築活動に関する研究」(東京大学学位論文、1993 年)、同『図説[满州] 都市物語」(河出書房新社、1996 年)、同『海を割った日本人建築家 20 世紀前半の中国東北地方における建築活動」(彰国社、1996年)、西田貴志 『南满州の近代建築」(私家版、1996 年)、西澤泰彦『図説满鉄「满州」の 巨人」(河出書房新社、2000 年) など。

2）入来晴之ほか 2 名「伊藤組の旧檴太・朝鮮における建築請負活動一北海道

3）井榈裕、越野武、角幸博、高橋 学「南サハリンにおける日本統治期 $(1905$

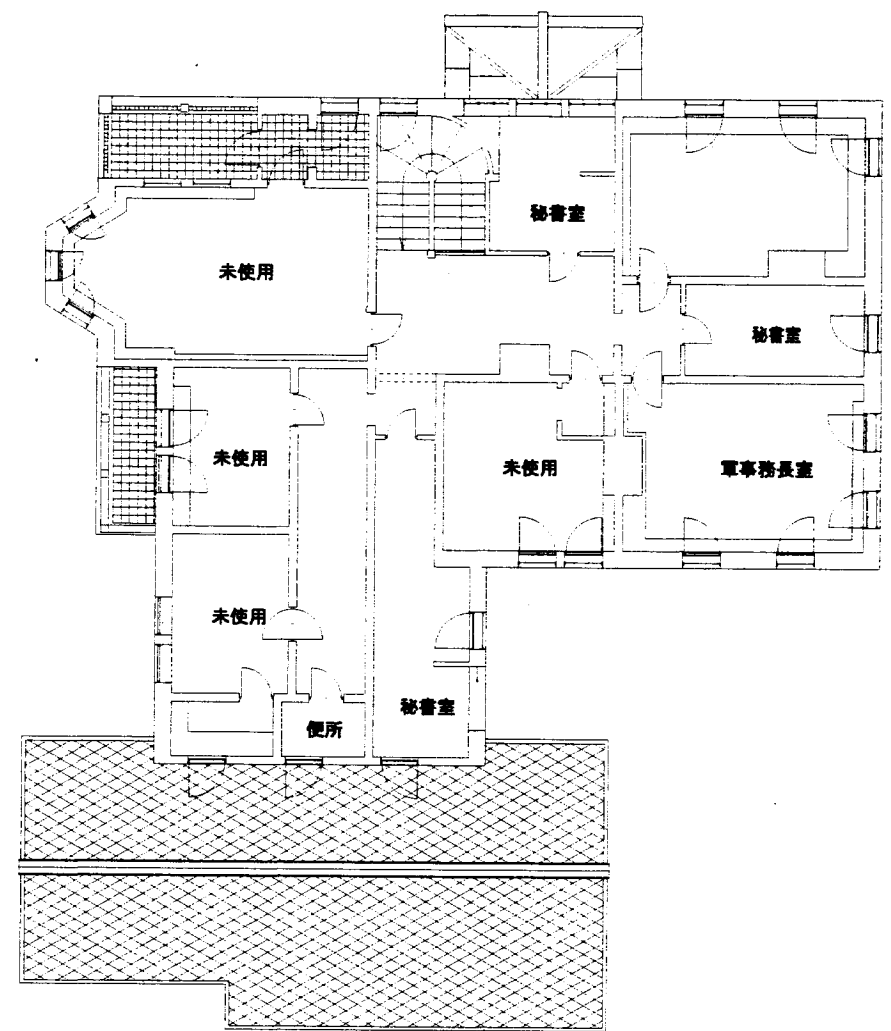

図 4 2 階平面図（現況）

戦前期の建設業者に関する研究 (1)」(日本建築学会北海道支部研究報告

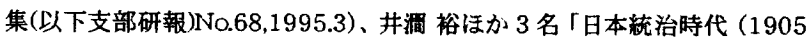
～1945）におけるサハリン(旧槿太)の建築（1）コルサコフ (旧大泊)」

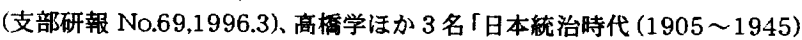
におけるサハリン(旧楛太)の建築 (2) ユジノサハリンスク (旧豊原)」(支 部研報No. 69,1996.3)、高橋学ほか 3名「南サハリンにおける日本統治 初期(1905 1915)の建設活動と学䜌組織」(支部研報No.70, 1997.3)、 井浻裕ほか 3 名「日本統治期の南サハリンにおける建設請負業者」(支部 研報No.71，1998.3)、高橋学ほか3 名「樺太日日新聞にみる昭和初期南节 ハリンの建築活動」(支部研報No.71, 1998.3)、井润裕ほか 2 名「樺太庁 技師貝塚良雄(1900-1974)の経歴と建築活動」(支部研報No.72, 1999.3)、 Hiroshi Itani, Takeshi Koshino, Yukihiro Kado "Some Aspects of Building Construction in Southern Sakhalin during Japanese Colonial Age(1905-1945): Buildings, Architects, Contractors and Building Sections of Government Offices" (ACTA SLA VICA IAPONICA, 17、2000)、井淍裕 $\mathbf{P}$ 日本期の南サハリンにおける建設活動に関する研究」 (北海道大学学位論文、2000) などがある。

〜 1945)建築の現存状況」(日本建築学会技術報告集 No.5, 1997.12)、

4）守備隊司令官官舎及附属家他一廉新営工事」(工事請負契約書, 株式会社伊 藤組土建所藏による

5)注 4)に同

6）全国樺太連盟 P㩰太行政治革史」（1978）p.310

7）䧕員録」(明治 41 年)

8）僟員録」(明治 40 年)

9 ）第 7 師団経理部から転任。東京工手学校 1898 (明治 31 )年卒業。1907 年前 後から 1909 年度まで在職。

10）第 7 師団経理部から転任。1907～1908年在職。1909年には苹太庁技手。

11） 1904 年東京工手学校卒業。1907 1909 年在職。

12）東京帝国大学工科大学建築学科 1906 年卒業。同年 7 月 13 日民政署に赴 任。在職は 1907 年 1 月頃まで。

13）「前陸軍勅任技師、工学士田村鎮君の業界に於いての功續や、特にすくれ た住宅建築に於ける地位については、私以外に書く人も多からうし、ま た周知の事実なのだから」(『建築稌就」昭和 17 年 4 月号「田村鎮君を 悼む」(中村与資平)上り)

[2001年 4 月20日原稿受理２001年 7 月27日採用決定］ 